Chem. Chem. Technol., 2019,

Chemical

Vol. 13, N o. 2, pp. 254- 260

Technology

\title{
FOOD ADDITIVES AS FACTOR OF CORROSION OF MILD STEEL IN NEUTRAL SOLUTION
}

\author{
Olena Bondar1, Victoria Vorobyova ${ }^{2}$, Margarita Skiba ${ }^{3}$, Iryna Kurmakova1, *, \\ Natalia Demchenko ${ }^{1}$, Olena C hygyrynets ${ }^{2}$
}

https://doi.org/10.23939/chcht13.02.254

\begin{abstract}
It has been showed that food additives E451 and E459 inhibit corrosion in neutral water-salt medium and additives E316, E631, E621, E631+E551, herbs and spices increased it up to 1.75 times. Under microbial corrosion condition, inducted by sulfate-reducing bacteria, inhibition action (up to $80.9 \%$ ) was discovered only for additive E459. Other studied additives increased microbial corrosion up to 2.27 times. The presence of food additives in corrosive medium influences the quantity of sulfatereducing bacteria in biofilm on steel surface.
\end{abstract}

Keywords: corrosion, biocorrosion, neutral medium, sulfate-reducing bacteria, mild steel, food additives.

\section{Introduction}

During operation industrial equipment simultaneously undergoes several types of corrosion. Approximately $50 \%$ of corrosion cost is due to microbiologically influenced corrosion $[1,2]$. The following types of industrial objects are exploited in a neutral medium and also destroyed with the participation of microorganisms: equipment for treatment facilities, drainage and water treatment, industrial equipment, etc. In particular, during the operation of treatment facilities (especially at the initial stages of water treatment in the presence of a sufficient amount of nutrients) in anaerobic conditions a sulfidogenic biofilm is formed - the place of active corrosion processes - on the surface of metal structures $[1,3]$. The necessary amount of nutrients in the corrosive medium - sources of carbon and sulphur facilitates the increase in the number of bacteria and the aggressiveness of biofilm. These substances include food

\footnotetext{
${ }^{1}$ Chernihiv National T.G. Shevchenko Pedagogical University,

53, Hetmana Polubotka St., 14013 Chernihiv, Ukraine

${ }^{2}$ National Technical University of Ukraine "Igor Sikorsky Kyiv

Polytechnic Institute",

37, Peremogy Ave., 03056 Kyiv, Ukraine

${ }^{3}$ Ukrainian State University of Chemical Technology,

8, Gagarin Ave., 49005 Dnipro, Ukraine

*i.kurmakova@gmail.com

(c) Bondar O., Vorobyova V., Skiba M., Kurmakova I.,

Demchenko N., Chygyrynets O., 2019
}

additives that are widely used and enter the sewage as domestic and industrial waste water.

Most studies on corrosion of water treatment equipment are devoted to determining the quantity of corrosive microorganisms, the composition of microbial groups, their seasonal dynamics, and the influence of temperature on the rate of corrosion processes [4-6]. The influence of the composition of sewage and its individual components on the intensity of the occurrence of corrosive processes, including the participation of microorganisms is practically not investigated. Corrosive activity of food additives was studied mainly in the case of corrosion of aluminum and steel in acidic media [7, 8]. Taking into account the widespread use of food additives in industry and everyday life, it is relevant to clarify the technological risk and ensure the stable operation of technological equipment for treatment plants by studying food additives as a factor of corrosion of steel and determining their impact on the microbiological factor.

The aim of the present work was to study the corrosion behavior of mild steel in aqueous neutral watersalt medium containing food additives, with and without corrosion-aggressive microorganisms.

\section{Experimental}

Food additives (Table 1), recommended by the Codex General Standard for Food Additives CODEX STAN 192-1995 (GSFA), were selected for the study. Individual food additives and a mixture of spices (herbs and spices) were investigated. According to the code of GSFA grade, category 'Herbs and spices' describes items the use of which is intended to enhance the aroma and taste of food. 12.2.1 Herbs and spices: Herbs and spices are usually derived from botanical sources, and may be dehydrated, and either ground or whole. Examples of herbs include basil, oregano and thyme. Examples of spices include cumin and caraway seeds. Spices may also be found as blends in powder or paste form. Examples of spice blends include chilli seasoning, chilli paste, curry paste, curry roux, and dry cures or rubs that are applied to external surfaces of meat or fish. 
Table 1

\section{Studied food additives}

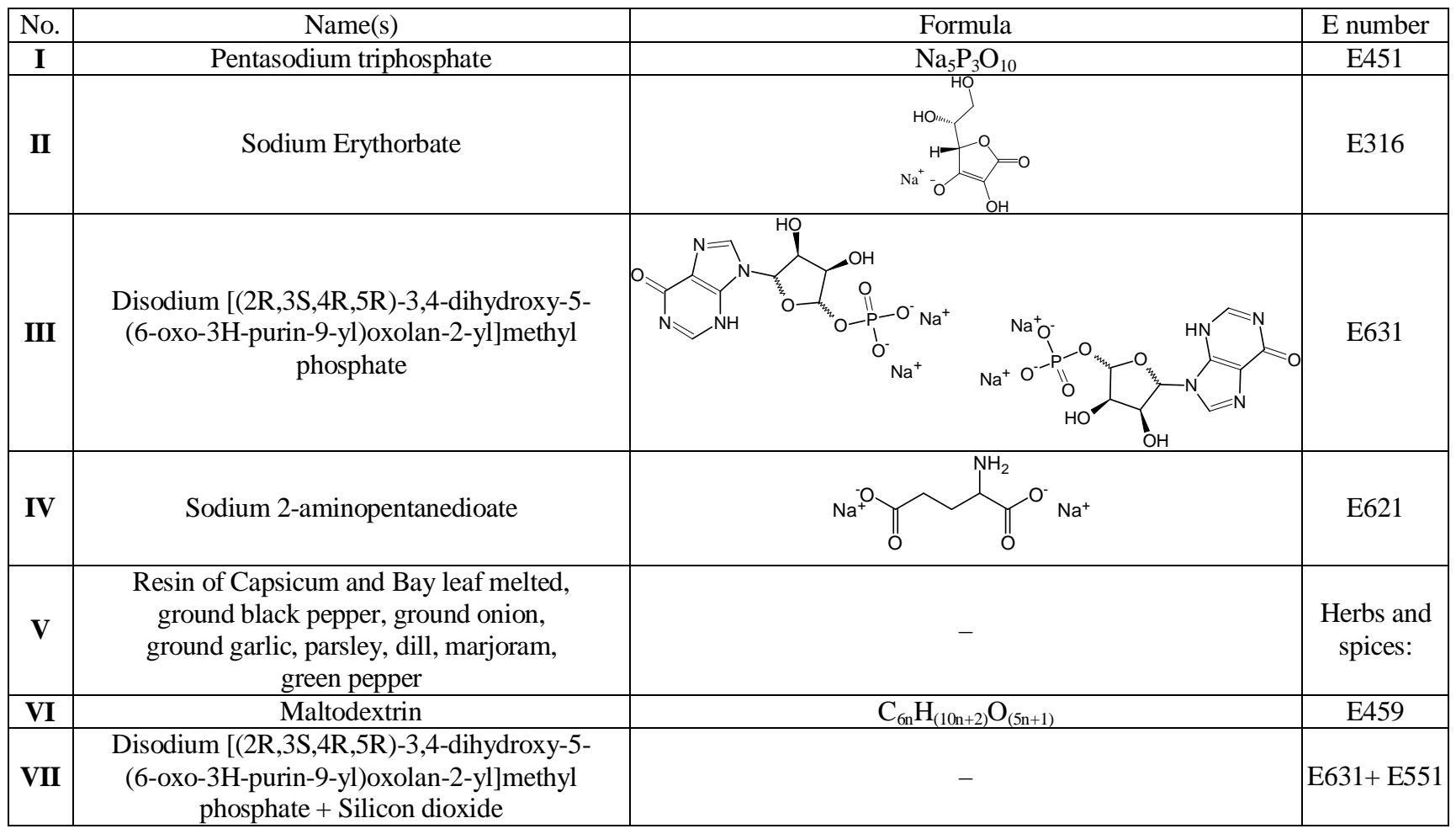

The corrosion tests were performed with the help of gravimetric and electrochemical methods [9]. The mild steel St3ps coupons (surface area $0.002 \mathrm{~m}^{2}$ ), polished to the 4-5 class of accuracy, were used for the gravimetric testing. Before being placed in the corrosive medium, the steel samples were cleaned with acetone, and weighed with analytical scales accurate to $5 \cdot 10^{-5} \mathrm{~g}$. The samples soaking time was $240 \mathrm{~h}$ at $300 \mathrm{~K}$. Corrosion rate with or without the inhibitors was calculated with the help of the formula: $k_{m}=\Delta m /(S \cdot \tau)$, were $\Delta m$ - weight loss, g; $S-$ area, $\mathrm{m}^{2} ; \tau$ - exposure time, h. Corrosion inhibition coefficient was calculated with the help of the formula: $\gamma_{m}=k_{m} / k_{m}{ }^{\prime}$, where, $k_{m}$ and $k_{m}{ }^{\prime}$ is the corrosion rate without and with the inhibitor. The inhibition efficiency was calculated using the following equation: $I E=1-1 / \gamma_{m}$.

Electrochemical tests were performed with the help of potentiostat PI-50-1.1 and programmer PR-8. In this test a cylindrical steel electrode made of St3ps steel had been molded into Teflon casing. The preparation of the electrode surface to the testing included polishing, washing with distilled water and with the studied solution. Three-electrode cell with the separated cathode and anode scope was used. Polarization curves were measured from the potential of free corrosion to $0.7 \mathrm{~V}$ and from -0.7 to $0 \mathrm{~V}$. Chloride silver electrode $(E=0.22 \mathrm{~V})$ was used as a comparison electrode, which was conducted to the steel electrode with the help of electrolytic bridge and Lugin capillary. The extra electrode was a platinum one. The electrode potentials, provided in the paper, were recalculated in accordance with the common hydrogen electrode. The results are presented as data curves of the correlation between the voltage $(E, \mathrm{~V})$ and current density logarithm $\left(\lg i,\left(i, \mathrm{~A} / \mathrm{cm}^{2}\right)\right)$. The calculated data were: potential and current of free electrochemical corrosion $\left(E_{\text {corr }}, i_{\text {corr }}\right)$, corrosion inhibition coefficient $\left(\gamma_{c}=i_{\text {corr }} / i_{\text {corr }}\right.$, where $i_{\text {corr }}, i_{\text {corr }}{ }^{\prime}$ - corrosion current without the food additives and with the food additives, respectively) and inhibition efficiency $I E_{c}=1-1 / \gamma_{c}$.

Model medium Postgate "B" [10] with and without enrichment culture of sulfate-reducing bacteria (SRB) was used as a testing corrosive medium. Postgate " $\mathrm{B}$ " medium composition per liter: $\mathrm{KH}_{2} \mathrm{PO}_{4}-0.5 \mathrm{~g}$; $\mathrm{NH}_{4} \mathrm{Cl}-1.0 \mathrm{~g}$; $\mathrm{CaSO}_{4} \cdot 2 \mathrm{H}_{2} \mathrm{O}-1.0 \mathrm{~g} ; \mathrm{MgSO}_{4}-2.0 \mathrm{~g}$; calcium lactate $3.5 \mathrm{~g}$; yeast extract $(5 \%)-10 \mathrm{ml} ; \mathrm{FeSO}_{4} \cdot 7 \mathrm{H}_{2} \mathrm{O}(5 \%$ solution in $1 \% \mathrm{HCl})-10 \mathrm{ml}$; ascorbic acid $(5 \%)-2 \mathrm{ml}$; $\mathrm{NaHCO}_{3}(5 \%)$ - in the amount (ml) necessary to adjust $\mathrm{pH}=7.5$. The acidity was measured with $\mathrm{pH}-\mathrm{me}-$ ter/ionomer $\mathrm{pH} / \mathrm{ION} 340 \mathrm{i}$.

The culture of sulfate-reducing bacteria was obtained with the enrichment culture method in the liquid elective medium Postgate " $\mathrm{B}$ " from the biofilm, gathered from the metal equipment surfaces of sewage treatment constructions (Chernihiv) [11]. This culture was used for modeling the biocorrosion process. 
Initial titre of sulfate-reducing bacteria in corrosive medium was $10^{9} \mathrm{cell} / \mathrm{ml}$. The number of bacteria (in selected biofilm samples, in corrosive medium, in biofilm, which appeared on the metal samples surface during the tests) was calculated using the method of decimal serial dilution during the bacteria seeding to the correspondent liquid selective mediums: sulfate reducing bacteria - to the Postgate " $\mathrm{B}$ " medium. The biofilm cells which appeared on the surface of steel samples during tests were gathered into the fixed volume $(20 \mathrm{ml})$ of $0.1 \mathrm{~N}$ phosphate buffer ( $\mathrm{pH} 7$ ) with the help of ultrasound with a frequency of $25 \mathrm{kHz}$ (30 s) twice using UZM-003/n. The resulting swab was used in cultivating and calculating the adhered bacteria cells [12].

Food additives concentrations were 1 and $3 \mathrm{~g} / \mathrm{l}$.

The degree of influence $(S, \%)$ of the studied food additives on bacteria sulfate reduction was calculated using the formula: $S=\left(\left(C-C^{\prime}\right) / C^{\prime}\right) \cdot 100 \%$, where $C$ and $C^{\prime}$ - the average hydrogen sulphide concentration with and without the food additives, respectively, $\mathrm{mg} / \mathrm{l}$. The concentration of biogenic hydrogen sulfide was measured by iodometric titration [13].

For surface analysis, the biofilms on steel surface were examined with scanning electron microscope (SEM). To fix the grown biofilm to the steel surface, the coupons were immersed for $1 \mathrm{~h}$ in $2 \%$ glutaraldehyde solution, dehydrated with 4 ethanol solutions (15 min each) of 25, 50, 75, and $100 \mathrm{vol} \%$ successively, and air dried overnight [14]. After fixation, the coupons were examined using field emission scanning electron microscopy FEIE-SEM XL 30. With the help of electron microscope, the picture was taken in the mode of functioning in secondary electrons. Maximum residual pressure in the microscope pillar was no more than $6.7 \cdot 10^{-4} \mathrm{~Pa}$ under the gun current of $76 \mathrm{~mA}$.

Energy dispersive spectrum (EDS) was used to analyze the elemental composition of corrosion products. Before EDS (X-max 50, Japan) analysis of the biofilms and corrosion products, the coupons were pretreated by being soaked in a phosphate buffer solution containing $2.5 \%$ $(\mathrm{w} / \mathrm{w})$ glutaraldehyde for $8 \mathrm{~h}$ in order to immobilize the biofilms to the coupon surface. Afterwards, all the coupons were dried with a nitrogen gas stream and placed in desiccators. The composition of corrosion products on the coupon was analyzed by X-ray diffraction (XRD). XRD patterns were recorded by a diffractometer within 283-363 K $2 \theta$ with $\mathrm{Cu} \mathrm{K} \alpha$ radiation at a rating of $40 \mathrm{kV}, 20 \mathrm{~mA}$.

\section{Results and Discussion}

The studied food additives have an impact on the St3ps steel corrosion rate in water-salt medium Postgate "B" (Fig. 1). In the absence of SRB, food additives $\mathbf{I}$ and VI showed inhibition action of 37.9 and $12.3 \%$, respectively. This is due to the nature of the substances, in particular, the additive I refers to phosphates, which are known as steel corrosion inhibitors [15, 16]. Additive VI is a polymer with hydroxyl functional groups, which provides its surface activity in aqueous solutions and promotes adsorption on the metal surface.

Food additives II-V and VII increase the corrosion rate by $1.18-1.75$ times. Probably, these compounds do not have the ability to adsorb on the steel surface. But organic anions, which are formed under salts dissociation, form soluble chelate complexes with iron ions. This behavior in the conditions of electrochemical corrosion accelerates the anode reaction of metal dissolution.

The results obtained by weight loss and potentiodynamic polarization methods are in good agreement.

Fig. 2 shows the polarization curves for mild steel in medium Postgate "B" with and without food additives I and VI, which were corrosion inhibitors. These dependences of the current density on the electrode potentials indicate the presence of fairly complicated multistage processes under the conditions of cathodic and anodic polarization of steel. The anodic curve for the steel electrode in water-salt solution exhibits an active behavior. The cathodic portion of the polarization curve for the blank solution is a composite and represents oxygen reduction.

Both the cathodic slopes and the anodic slopes do not change obviously, which indicates that the mechanism of the corrosion reaction does not change and the corrosion reaction is inhibited by a simple adsorption mode. The corrosion potential $\left(E_{c o r r}\right)$ is not obviously changed. As a result of food additives presence, the potential shifts to the negative side to $0.02-0.03 \mathrm{~V}$ (Table 2). On the other hand, the presence of these inhibitors shifts both anodic and cathodic curves to lower values of current densities to a bigger extent and increases the polarization of electrode processes. In other words, the inhibitor decreases the surface area for corrosion without affecting the corrosion mechanism and causes only inactivation of a part of the metal surface. It is also seen that all these samples shift the corrosion potential significantly to negative direction, therefore they are predominantly anodic-cathodic inhibitors. It can be seen that the inhibition effectiveness of food additive I (pentasodium triphosphate) is higher than VI (maltodextrin).

Corrosion rate of St3ps steel in water-salt medium Postgate " $\mathrm{B}$ " in the presence of SRB culture is 2.3 times higher than without bacteria (Fig. 1). Food additives I-III, V and VII ( $3 \mathrm{~g} / \mathrm{l})$ increase microbial corrosion of steel, maximally by 2.27 times with additive $\mathbf{V}$. This is due to the active formation of hydrogen sulfide by bacteria in the presence of additive $\mathbf{V}$ (Table 3 ) and, accordingly, a significant increase in the acidity of the corrosive medium. Additive IV has practically no effect on the corrosion rate and additive VI shows inhibition efficiency of $80.9 \%$. It should be noted that under conditions of microbial corrosion, the influence of food additive $\mathbf{I}$, 
which is a corrosion inhibitor $(I E=36.7 \%)$ in medium without bacteria, turned out to be the opposite. This compound may be an additional source of power for SRB, which leads to an increase in the number of bacteria in a biofilm to $10^{8}$ (Table 3).

Inhibition efficiency of food additive VI is higher by $68.6 \%$ in corrosive medium with SRB as compared to medium without bacteria.

For food additives IV and VI, which showed inhibition efficiency, the biggest influence on the quantity of SRB has been determined. At the presence of food additive IV, the quantity of SRB showed decrease to $10^{4} \mathrm{cell} / \mathrm{ml}$ as in solution. Additive VI has an impact only on biofilm formation and less strong on SRB quantity

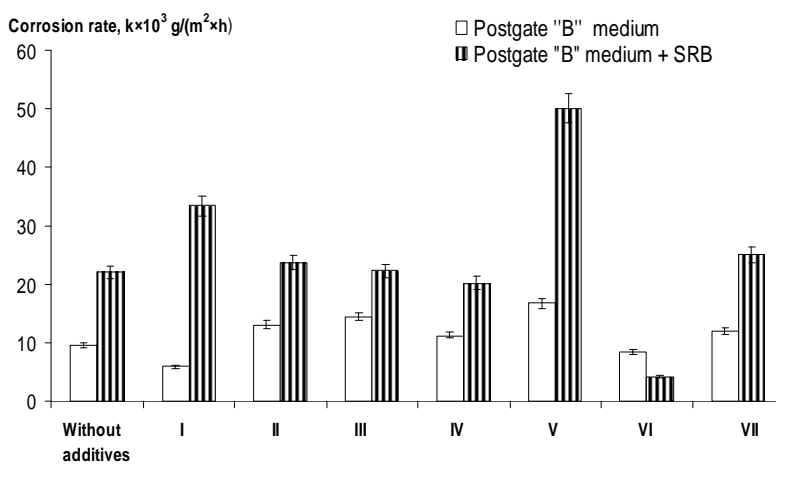

Fig. 1. Food additives ( $3 \mathrm{~g} / \mathrm{l})$ impact on the St3ps steel corrosion rate in corrosive medium Postgate "B" with and without SRB culture
(Table 3). The decrease in the number of bacteria led to the decrease in the concentration of biogenic hydrogen sulfide and, accordingly, corrosive aggressiveness of the medium.

With a decrease in the concentration of food additives to $1 \mathrm{~g} / \mathrm{l}$, their influence on microbial corrosion indicators is slightly reduced.

When the results were analyzed, a correlation between the steel inhibition coefficient logarithm under the biocorrosion and the biogenic hydrogen sulphide concentration - the main metabolite of SRB - has been established (Fig. 3). Thus, the influence of food additives on St3ps steel microbial corrosion is caused by their action on microbiological factor.

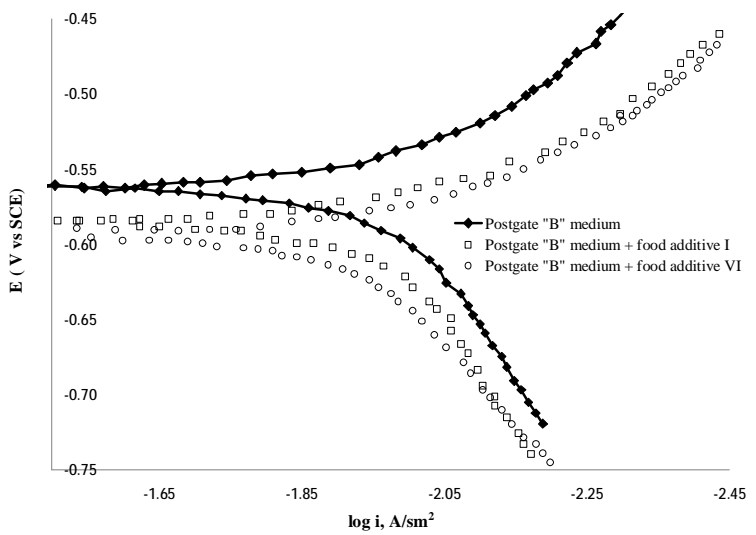

Fig. 2. Polarization curves for St3ps steel in water-salt medium Postgate "B" with and without food additives I (pentasodium triphosphate) and VI (maltodextrin) (3 g/l)

Table 2

Polarization parameters for mild steel in the presence/absence of food additives

\begin{tabular}{|l|c|c|c|c|}
\hline \multicolumn{1}{|c|}{ System } & $E_{\text {corr }, \mathrm{V}}$ & $i_{\text {corr }}, \mathrm{A} / \mathrm{cm}^{2}$ & $\gamma_{c}$ & $I E_{c}, \%$ \\
\hline Without food additives & -0.55 & $6.8 \cdot 10^{-3}$ & - & - \\
\hline Food additive I (pentasodium triphosphate) & -0.58 & $3.4 \cdot 10^{-3}$ & 1.6 & 37.5 \\
\hline Food additive VI (maltodextrin) & -0.57 & $4.5 \cdot 10^{-3}$ & 1.5 & 33.3 \\
\hline
\end{tabular}

Table 3

\section{Influence of various concentrations of food additives on parameters of microbial corrosion of steel St3ps}

\begin{tabular}{|c|c|c|c|c|c|c|c|c|}
\hline \multirow[b]{2}{*}{$\begin{array}{l}\text { Food } \\
\text { additive }\end{array}$} & \multirow{2}{*}{$\begin{array}{c}\text { Corrosion } \\
\text { inhibition } \\
\text { coefficient } \\
\gamma_{m}\end{array}$} & \multirow{2}{*}{$\begin{array}{c}\text { Concentration of } \\
\text { hydrogen sulfide } \\
C, \mathrm{mg} / \mathrm{l}\end{array}$} & \multirow{2}{*}{$\begin{array}{l}\text { The degree of } \\
\text { influence on } \\
\text { bacterial sulfate- } \\
\text { reduction } S, \%\end{array}$} & \multirow{2}{*}{$\begin{array}{c}\text { Corrosion } \\
\text { inhibition } \\
\text { coefficient } \gamma_{m}\end{array} \mid$} & \multirow{2}{*}{$\begin{array}{c}\text { Concentration of } \\
\text { hydrogen sulfide } \\
C, \mathrm{mg} / \mathrm{l}\end{array}$} & \multirow{2}{*}{$\begin{array}{l}\text { The degree of } \\
\text { influence on } \\
\text { bacterial sulfate- } \\
\text { reduction } S, \%\end{array}$} & \multicolumn{2}{|c|}{$\begin{array}{l}\text { Quantity of sulfate- } \\
\text { reducing bacteria }\end{array}$} \\
\hline & & & & & & & $\begin{array}{c}\text { In solution, } \\
\text { cell } / \mathrm{ml}\end{array}$ & \begin{tabular}{|c|} 
In \\
biofilm, \\
cell $/ \mathrm{cm}^{2}$
\end{tabular} \\
\hline & \multicolumn{3}{|c|}{$1 \mathrm{~g} / 1$} & \multicolumn{5}{|c|}{$3 \mathrm{~g} / 1$} \\
\hline- & - & 716 & - & - & 716 & - & $10^{7}$ & $10^{5}$ \\
\hline $\mathrm{I}$ & 0.73 & 702 & -2 & 0.66 & 916 & +28 & $10^{7}$ & $10^{8}$ \\
\hline II & 0.78 & 745 & +4 & 0.93 & 931 & +30 & $10^{8}$ & $10^{6}$ \\
\hline III & 0.98 & 795 & +11 & 0.99 & 952 & +33 & $10^{\prime}$ & $10^{5}$ \\
\hline IV & 0.97 & 659 & -8 & 1.09 & 730 & +2 & $10^{4}$ & $10^{4}$ \\
\hline $\mathrm{V}$ & 0.51 & 831 & +16 & 0.44 & 1554 & +117 & $10^{7}$ & $10^{6}$ \\
\hline VI & 2.21 & 587 & -18 & 5.24 & 143 & -80 & $10^{\prime}$ & $10^{4}$ \\
\hline VII & 0.80 & 802 & +12 & 0.88 & 988 & +38 & $10^{8}$ & $10^{5}$ \\
\hline
\end{tabular}




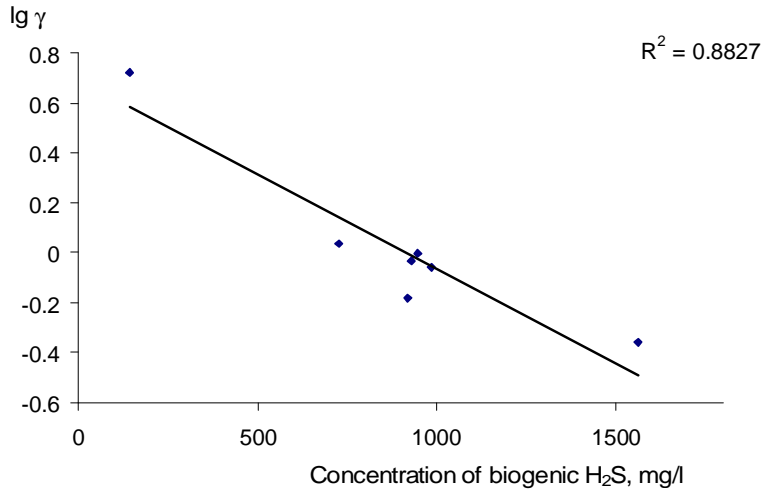

Fig. 3. Correlation between the inhibition coefficient $\operatorname{logarithm}(\lg \gamma)$ and biogenic hydrogen sulphide concentration (food additives concentration $3 \mathrm{~g} / \mathrm{l}$ )

For a more detailed study additive I (increases microbial corrosion) and additive VI (has inhibitor action) were chosen. SEM analyses were conducted in order to characterize the protective layer that formed on the mild steel surface.

The photos of the steel St3ps surface samples with biofilm formed during exposure in a corrosive medium without food additives and with additives I and VI, differ significantly. In the absence of food additives biofilm (Fig. 4) represents the accumulation of bacteria which are unevenly distributed in the polymer matrix.

Scanning electron micrographs in Fig. 4 shows reduction of sulfate reducing bacteria on mild steel surfaces. There is a high density of microorganisms on separate plots. The adsorbed cells form lush colonies. Bacteria morphology is curved rod and they have the length of approximately $4 \mu \mathrm{m}$. These are general characteristics of SRB [17].

The EDS results of biofilm chemical compositions show that the main elements are $\mathrm{C}, \mathrm{Fe}, \mathrm{S}$, and $\mathrm{O}$ (Fig. 5a). Carbon and oxygen should be attributed to the polymer matrix, which, as is known [1], consists of saccharide residues. Oxygen peak was also revealed by the analysis, due to the exposure to oxygen during the handling process. The presence of sulphur indicates the formation of iron sulphides $\left(\mathrm{FeS}_{\mathrm{x}}\right)$. It leads to formation of sulphide micro galvanic pairs, where sulphides are cathode. Sodium, phosphorus and calcium found in small quantities are the components of Postgate " $\mathrm{B}$ " medium. Also, the presence of tiny cracks of the sulphide film should be noted (Fig. 4). In such biofilm, corrosion processes take place at a high rate, which is consistent with the data of gravimetry (Fig. 1).

For the analysis of scanning electron micrographs obtained, structural changes on the surface under influence of food additives were observed. Microphotography of a biofilm with food additive I, which accelerates microbial corrosion, illustrates the presence of black corrosion products, bacterial cells and exopolymer fibers (Fig. 6). The appearance is a gelatinous, oily mixture. EDS results (Fig. $5 \mathrm{~b}$ ) indicate elevated levels of oxygen and sodium in comparison with biofilm free of food additives, and the absence of Sulfur in the biofilm. Probably, the food additive I $\left(\mathrm{Na}_{5} \mathrm{P}_{3} \mathrm{O}_{10}\right)$ is capable of adsorption on the steel surface (this is consistent with the polarization measurements), but can be used by bacteria as a nutrient, in particular as additional source of phosphorus. This contributes to an increase of the quantity of bacteria in a biofilm up to $10^{8}$ cells $/ \mathrm{cm}^{2}$ (Table 3) and stimulates microbial corrosion. Formation of ferum sulfides is complicated, therefore, products of corrosion are oxygen-containing compounds.

Additive VI, which showed properties of corrosion inhibitor even in medium without bacteria, contributes to the formation of a biofilm (transparent in appearance substance) with protective properties (Fig. 7a). There are only separate bacteria on steel surface. The feature of elemental composition of biofilms is absence of $\mathrm{S}$ and $\mathrm{Na}$. At the same time, biofilm contains $\mathrm{Mg}$.

Fig. 8 displays the FE-SEM images of the steel surface after exposure to Postgate "B" medium with SRB culture and maltodextrin (a) and pentasodium triphosphate (b) after cleaning.

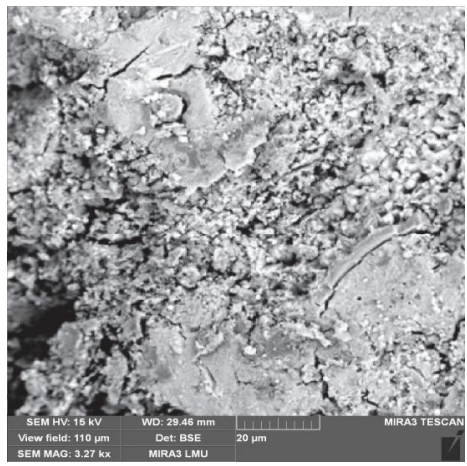

a)

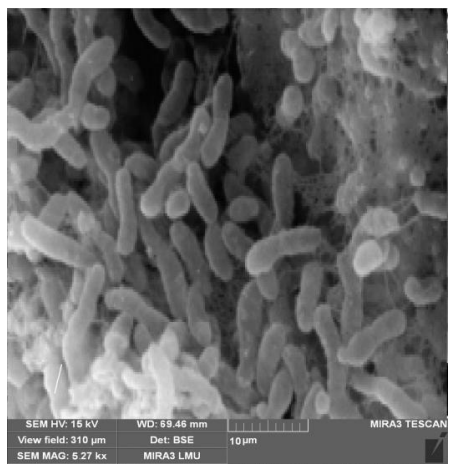

b)

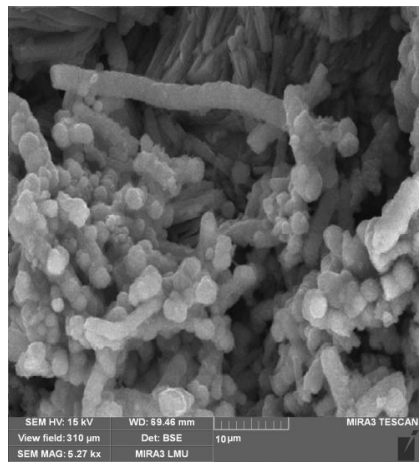

c)

Fig. 4. FE-SEM images for the biofilm developed on St3ps steel surface after exposure to Postgate "B" medium with SRB culture without food additives. Magnification of $1000 \times(a)$ and $8000 \times(b, c)$ 


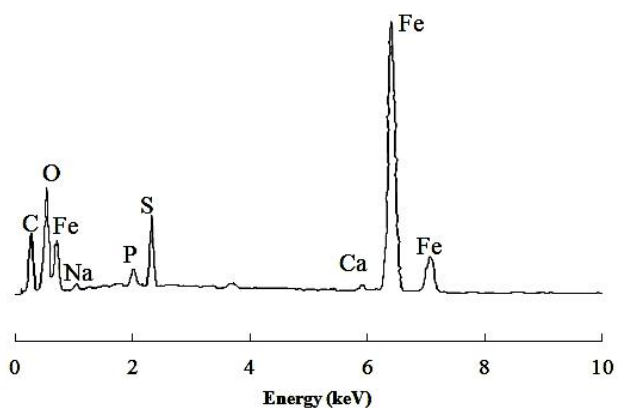

a)

Fig. 5. EDS analysis of corrosion products of steel immersed to Postgate "B" medium with SRB culture: without food additives (a); with pentasodium triphosphate (additive I) (b) and with maltodextrin (additive VI) (c)

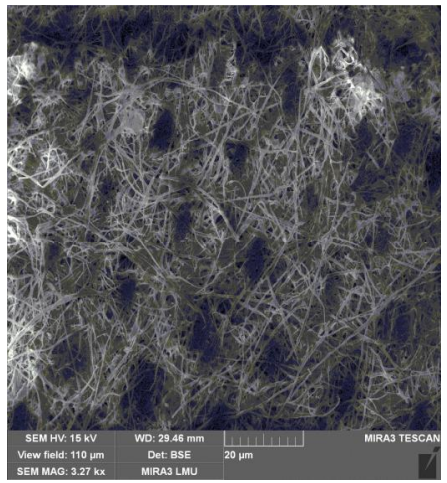

a)

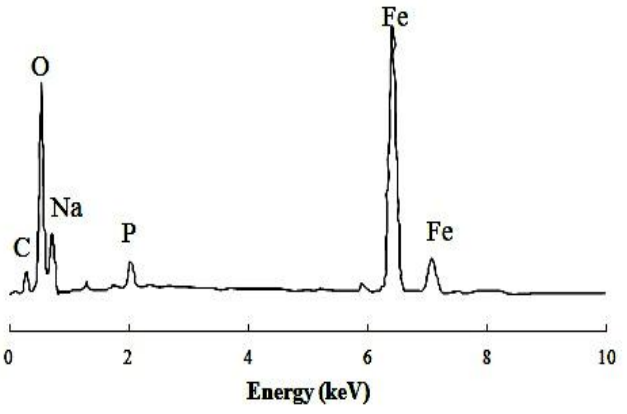

b)

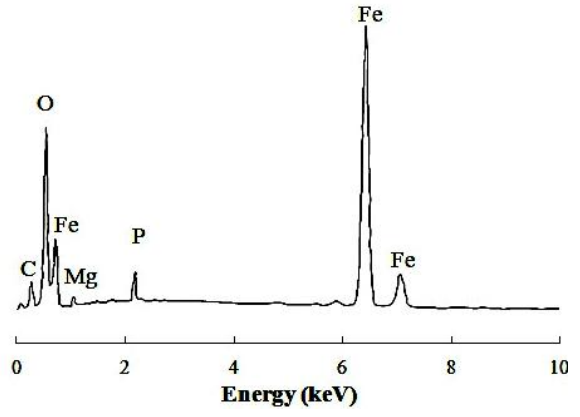

c)

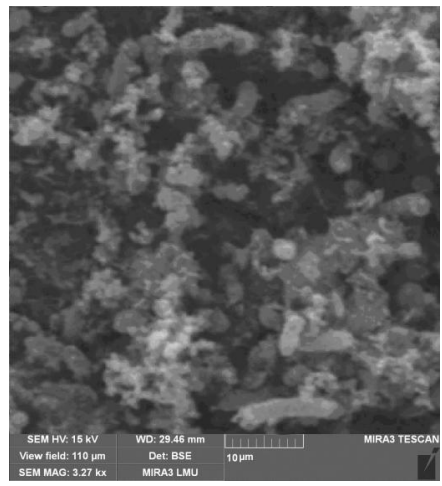

b)

Fig. 6. FE-SEM images for the biofilm developed on St3ps steel surface after exposure to Postgate "B" medium with SRB culture and pentasodium triphosphate (food additive I). Magnification of $1000 \times$ (a) and $8000 \times$ (b)

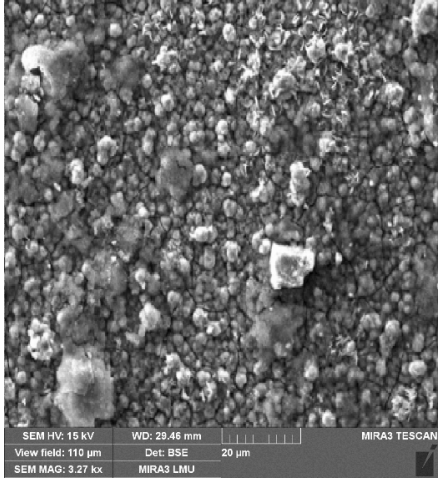

a)

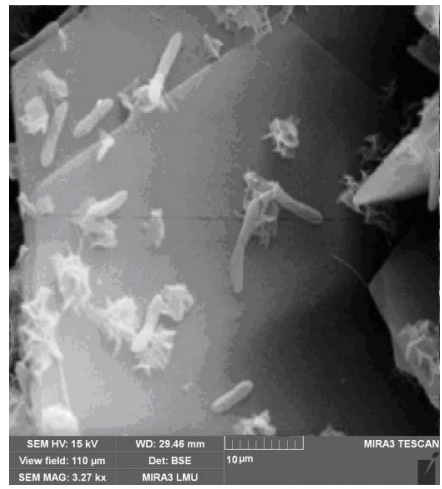

b)

Fig. 7. FE-SEM images for the biofilm developed on St3ps steel surface after exposure to Postgate "B" medium with SRB culture and maltodextrin (food additive VI). Magnification of $1000 \times$ (a) and $8000 \times(b)$ 


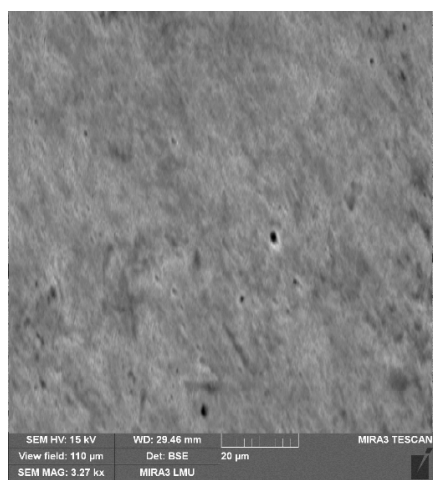

a)

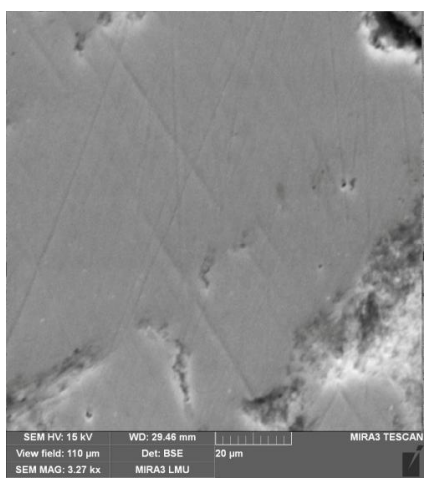

b)

Fig. 8. FE-SEM images for the clean surface after exposure in systems maltodextrin (a) and pentasodium triphosphate (b)

As demonstrated in Fig. 8, the steel surface shows uneven corrosion inhibition. Fig. 8 represents the FE-SEM images of the steel surface exposed to maltodextrin and pentasodium triphosphate. In comparison, the exposure of the system to maltodextrin has more corrosion damage than exposure to pentasodium triphosphate. The obtained data are consistent with the results of gravimetry and electrochemical studies.

\section{Conclusions}

Food additives have influence on mild steel corrosion rate both in neutral water-salt solution without bacteria and under the presence of the culture of sulfatereducing bacteria. Food additives E451 and E459 inhibit St3ps steel corrosion in neutral water-salt medium and additives E316, E631, E621, E631+E551, herbs and spices increase it up to 1.75 times. Under the microbial corrosion, induced by sulfate-reducing bacteria, only additive E459 shows inhibition action (up to $80.9 \%$, concentration $3 \mathrm{~g} / \mathrm{l}$ ). Other food additives increase corrosion rate up to 2.27 times. SEM and EDS analyses indicated that at the presence of pentasodium triphosphate and maltodextrin in corrosive medium biofilms are formed on steel surface, which are different in morphology and chemical composition. As a result, $3 \mathrm{~g} / \mathrm{l}$ of maltodextrin were identified as optimal dosage for inhibition of microbic corrosion with the efficiency of about $80.1 \%$, pentasodium triphosphate increases microbe corrosion by 1.52 times.

\section{References}

[1] Kozlova I., Radchenko O., Stepura L. et al.: Heokhimichna Diyalnist Mikroorganizmiv ta ii Prykladni Aspekty. Naukova dumka, Kyiv 2008.

[2] Korolev V., Ryzhenkov A., Gibalenko A.: Prom. Budivnictvo ta Inzhenerni Sporudy, 2009, 4, 7.

[3] Lin J., Ballim R.: African J. Biotechnol., 2012, 11, 15736. https://doi.org/10.5897/AJB12.2479

[4] Kearns J., Little B.: Microbiologically Influenced Corrosion Testing. American Society for Testing \& Materials, West Consohocken 1994.
[5] Coetser S., Cloete T.: Critical Reviews in Microbiology, 2005, 31, 213. https://doi.org/10.1080/10408410500304074

[6] Videla H.: Revista de Metalurgia, 2003, 39, 256.

https://doi.org/10.3989/revmetalm.2003.v39.iExtra.1128

[7] Murgayeva S.: Al'manakh Sovremennoy Nauki i Obrazovaniya, 2008, 11, 92.

[8] Peme T., Olasunkanmi L., Bahadur I. et al: Molecules, 2015, 20, 16004. https://doi.org/10.3390/molecules200916004

[9] Fokin M., Zhigalova K.: Metody Korrozionnykh Ispytanii Metallov. Metallurgia, Moskva 1986.

[10] Postgate J.: The Sulfate-Reducing Bacteria. Cambridge University Press, Cambridge 1984.

[11] Kurmakova I., Demchenko N., Bondar O. et al.: Second Int. Sci. Practice Conf. «Ukraine- EU. Modern Technology, Business and Law». Slovak Republic, Kosice 2016, 366.

[12] Egorov N.: Rukovodstvo k Prakticheskym Zaniatyiam po Microbiologii. Moskow Univ., Moskva 1983.

[13] Seheda A.: Analitychna Khimia. Kilkisnyi analiz. Fitosociocentr, Kyiv 2006.

[14] Xu C., Zhang Y., Cheng B., Zhu W.: Mater. Charact., 2008, 59, 245. https://doi.org/10.1016/j.matchar.2007.01.001

[15] Anaee R.: Arab. J. Sci. Eng., 2014, 39, 153. https://doi.org/10.1007/s13369-013-0865-x

[16] Lata S., Chaudhary R.: Ind. J. Chem. Technol., 2008, 15, 364. [17] Holt J., Krieg N., Sheath P. et al.: Bergey's Manual of Determinative Bacteriology, $9^{\text {th }}$ edn. Williams and Wilkins, Baltimore 1994.

Received: January 09, 2018/Revised: January 22, 2018/ Accepted: June 03, 2018

\section{ХАРЧОВІ ДОБАВКИ ЯК ЧИННИК КОРОЗІЇ НИЗЬКОКАРБОНОВОЇ СТАЛІ В НЕЙТРАЛЬНОМУ СЕРЕДОВИЩІ}

Анотація. Показано, щуо харчові добавки E451 та Е459 інгібують корозію сталі в нейтральному водно-сольовому середовищі, а добавки E316, E631, E621, E631+ E551 ma Herbs and spices пришвидшують іï в 1,75 рази. За умов мікробної корозї, ініиійованої сульфатвідновлювальними бактеріями, інгібуючу дію (до 80.9\%) виявлено лише для добавки Е459. Інші досліджені добавки пришвидиують мікробну корозію у 2,27 рази. Присутність харчових добавок в корозивному середовищуі впливає на чисельність сульфатвідновлювальних бактерій у біоплівці на поверхні сталі.

Ключові слова: корозія, біокорозія, нейтральне середовище, сульфатвідновлювальні бактерії, низьковуглецева сталь, харчові добавки. 